\title{
Kecakapan Literasi Media di Kalangan Generasi Milenial
}

\author{
Christina Arsi Lestari', Risqi Inayah Dwijayanti² \\ ${ }^{1}$ Program Studi Ilmu Komunikasi, Fakultas Ilmu Komunikasi, Universitas Mercu Buana \\ Kampus Meruya, Jl. Meruya Selatan No. 1 Kembangan, Jakarta Barat, 11650, Indonesia \\ ${ }^{2}$ Program Studi Ilmu Sosial dan Politik Universitas Satya Negara \\ J1. Sultan Iskandar Muda No.29, RT.4/RW.2, Kby. Lama Utara, Jakarta Selatan, 12240, Indonesia \\ Email: christina.arsi@mercubuana.ac.id ${ }^{1 *}$; inna.wijayanti@yahoo.com² \\ *Corresponding author
}

\begin{abstract}
Media literacy is the ability of audiences to media and mass media messages in the context of mass communication. The media literacymovement is also known as "media literacy" which is designed to increase individual controlover the media used. The research objective was to analyze media literacy skills among the millennial generation of students in the field of broadcasting at Mercu Buana University. The method used in this research is the case study method, through the interview stage with the informants, to describe the literacy skills possessed by students of the Mercu Buana University Broadcasting Study Program. The results of this study are in the form of informants' media literacy skills, it can be said that they meet the requirements of media literacy skills in accessing, analyzing, evaluating, and producing mass media messages both conventional and new media. The contribution of this research is to make the younger generation aware of the importance of having media literacy skills. That way the younger generation is able to become media literacy agents for the surrounding community. Keywords: Literacy Skills; Media Literacy; Millennial Generation
\end{abstract}

\begin{abstract}
Abstrak
Literasi media merupakan kemampuan khalayak terhadap media dan pesan media massa dalam konteks komunikasi massa. Gerakan literasi media dikenal juga dengan istilah "melek" media yang dirancang untuk meningkatkan kontrol individu terhadap media yang digunakan. Tujuan penelitian untuk menganalisis kecakapan literasi media di kalangan generasi milenial mahasiswa Bidang Studi Broadcasting Universitas Mercu Buana. Metode yang digunakan dalam penelitian ini adalah metode studi kasus, melalui tahapan wawancara dengan para Informan, untuk menggambarkan kecakapan literasi yang dimiliki oleh mahasiswa Prodi Broadcasting Universitas Mercu Buana. Hasil penelitian ini berupa kecakapan literasi media informan dapat dikatakan memenuhi syarat-syarat kecakapan literasi media dalam mengakses, menganalisis, mengevaluasi, dan memproduksi pesan media massa baik konvensional maupun media baru. Kontribusi penelitian ini untuk menyadarkan generasi muda bahwa pentingnya memiliki kecakapan literasi media, agar generasi muda mampu menjadi agen literasi media bagi masyarakat disekitarnya. Kata kunci: Kecakapan Literasi; Literasi Media; Generasi Milenial
\end{abstract}

\section{Pendahuluan}

Khalayak saat ini selalu diterpa dengan begitu banyak pesan melalui media baik dalam bentuk seperti poster, musik, acara televisi, hingga games. Khususnya khalayak anak-anak dan remaja yang sudah tidak bisa dipisahkan lagi dengan berbagai bentuk media massa. Perkembangan media dan teknologi tersebut dapat memberikan pengaruh, karena media massa bisa seperti dua wajah koin yang memberikan efek positif maupun negatif kepada khalayak.

Perkembangan teknologi media, diikuti juga dengan fungsi-fungsi media. Fungsi media antara lain yaitu memberikan informasi, mendidik, mempengaruhi (persuasi) dan menghibur (Qudratullah, 2016:44). Pada kasuskasus tertentu ketiga fungsi media tersebut, memiliki kepentingan dari pemilik modal. Misalnya berita di televisi yang terlihat sebagai lembaga penyampaian informasi, dibaliknya banyak pemberitaan yang dikonstruksi bahkan dikomodifikasi untuk kepentingan si pemilik modal. Tidak hanya itu saja, masih banyak lagi yang menunjukan bahwa realitas yang disampaikan media sering tidak objektif.

Contohnya berita 17 Januari 2020 tentang kopi biji salak dari sebuah stasiun televisi nasional. Hampir tiga menit televisi yang 


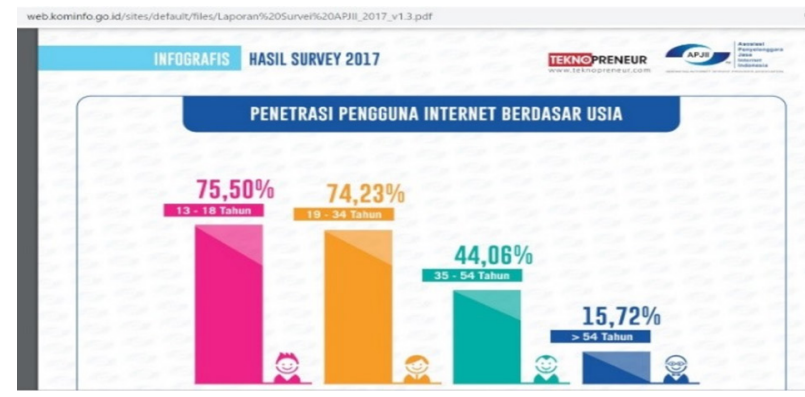

Gambar 1. Penetrasi Pengguna Internet Berdasar Usia Tahun 2017

Sumber: kominfo.go.id (2017)

menglaim sebagai televisi berita dengan bebas membuat narasi "menyesatkan." Gambar proses pembuatan "kopi" biji salak diselingi dengan pengakuan "sang penemu" tentang pengalaman sakit yang diderita ibunya "sembuh" karena meminum racikan "kopi" biji salak. Ditambah pula testimoni salah satu pelanggan tentang rasa minuman tersebut. Sayangnya hingga tayangan selesai, kita tidak mendapatkan penjelasan tentang klaim tersebut dari para ahli atau pemegang otoritas produk dagang Makanan dan Minuman (Terakota.id, 2020).

Jurnalisme televisi tersebut, mengabaikan pendidikan pada masyarakat bahwa untuk produk yang diklaim "bisa menyembuhkan penyakit". Mestinya harus melalui prosedur sebagai produk obat-obatan, bukan lagi produk makanan dan minuman. Fenomena "pengobatan alternatif" maupun klaim pengalaman sakit dan penyembuhan memang merupakan fakta atau kebenaran di tengah masyarakat kita. Namun media massa tidak cukup hanya menyajikan sepotong kebenaran seperti itu. Media massa mestinya tidak serta merta menjadikan hal tersebut sebagai kodifikasi mendapatkan materimateri liputan untuk medianya. Baik itu dalam bentuk features, straight news, maupun dalam bentuk spot news sekalipun (Terakota.id, 2020).

Hal ini sangat mengkhawatirkan karena saat tidak banyak khalayak media yang sadar akan hal tersebut sehingga tidak lagi dapat mengkritisi namun malah semakin terbawa dengan hegemoni media tersebut. Kehadiran media baru, seperti internet, khususnya media sosial juga memiliki efek yang cukup mengkhawatirkan. Penggunaan media sosial dan digital sudah seakan menyatu dalam kehidupan keseharian para remaja Indonesia.

Lembaga survei Gallup (2012) dalam salah satu laporannya menyebutkan bahwa satu dari lima orang di Indonesia $(20,6 \%)$ menggunakan internet dalam kehidupan mereka, dan dewasa ini, lebih setengah (51\%) penduduk muda Indonesia yang berusia antara 15-24 tahun telah menggunakan internet dalam aktivitas mereka. Sebagian besar penduduk muda ini $(96,2 \%)$ adalah pengguna media sosial (Morissan, 2014:53). Diperkuat lagi sampai tahun 2017 bahwa pengguna internet dikalangan pelajar ada sebesar 75,50\%.

Tabel 1 menggambarkan hasil studi yang dilakukan Kementerian Kominfo pada tahun 2017, mendata penggunaan internet dari berbagai usia, menemukan bahwa $75,50 \%$ pengguna internet ada pada rentang usia 13-18 tahun adalah kaum pelajar. Di posisi kedua $74,23 \%$ ada pada rentang usia 19-34 tahun adalah kaum mahasiswa dan pekerja. Beberapa catatan kasus akibat penggunaan internet khususnya media sosial mewarnai pemberitaan, seperti kasus penculikan berawal dari penggunaan Facebook, bahkan juga menjadi modus untuk penipuan, dan seperti contoh biji kopi di atas banyak konten-konten media sosial yang "menyesatkan" seperti prank yang dilakukan Youtuber Ferdian Paleka, dengan memberikan bingkisan berisi sampah kepada para transpuan. Kasus-kasus tersebut menunjukan bahwa pelajar ataupun mahasiswa masih belum memiliki filter dalam mencegah dan melindungi diri dari efek media massa dan media sosial.

Meningkatnya jumlah pengguna internet di Indonesia pada satu sisi menumbuhkan harapan besar akan semakin maju dan berkembangnya masyarakat Indonesia dari segi pemikiran karena terbukanya cakrawala pengetahuan sebagai akibat aliran informasi yang diterima. Selain itu 
semakin menumbuhkan daya kreatifitas bangsa Indonesia untuk mengembangkan dan membuat produk-produk yang lebih kreatif, inovatif dan kompetitif karena banyak contoh model yang dapat dikembangkan dan dapat disaingkan di pasar global sehingga dapat menopang pertumbuhan perekonomian nasional (Setianto, 2018:76).

Aspek-aspek fungsional bersifat positif dari teknologi internet yang melahirkan media online ini menjadi harapan baru bagi tumbuhnya sebuah masyarakat yang lebih inklusif dalam kerangka memajukan kehidupan bersama yang lebih kondusif, damai dan toleran. Teknologi yang diadopsi dalam kehidupan sosial, media online selain fungsional untuk tujuan-tujuan yang positif dapat juga bersifat disfungsional baik secara personal maupun secara sosial. Secara personal seseorang dapat menjadi tenggelam dalam keasyikan pencarian atau permainan di dunia maya sehingga terkungkung dalam lingkungan realitas simbolik yang subyektif dan egoistik. Secara sosial menyebabkan seseorang menjadi abai terhadap waktu dan kewajiban-kewajiban hidup lainnya dalam kehidupan sosialnya (Setianto, 2018:76).

Hal yang lebih mengkhawatirkan adalah internalisasi lingkungan realitas simbolik dunia maya ke dalam lingkungan realitas psikologis individu dan manifestasinya terhadap realitas empiris dalam kehidupan sosial. Satu hal yang tidak dapat dipungkiri sebagai hasil interaksi dari media online pada individu adalah pempribadian pengetahuan dan nilai-nilai simbolik dari realitas simbolik yang diperolehnya di media online. Pengetahuan dan nilai-nilai simbolik dari dunia maya dijadikan sebagai pengetahuan dan nilai-nilai pribadi yang memberikan arah dan petunjuk perilaku tentang sesuatu yang diyakini sebagai benar dan salah. Sepanjang hal tersebut masih berada pada realitas psikologis individu dampaknya tentu hanya pada individu itu sendiri. Masalah timbul apabila pengetahuan dan nilai-nilai hasil dari realitas simbolik tersebut diekspresikan dalam tindakan simbolik melalui media ataupun dalam bentuk tindakan sosial. Tentu hal ini akan menjadi permasalahan dalam kaitannya dengan ketertiban dan keamanan sosial (Setianto, 2018:76).

Perkembangan televisi dan internet telah membawa kecemasan baru, yaitu masalah isi (content) media, yang diyakini banyak menghadirkan program siaran yang tidak mendidik. Media interaktif yang semakin murah dan tersebar juga menghadirkan kecemasan tersendiri. Situs pornografi, permainan online, media sosial telah menyita waktu dan perhatian pelajar sehingga menyita waktu dan perhatian dalam belajar. Konsep berinternet yang sehat sulit untuk diterapkan karena sifatnya yang sangat personal. Pemahaman literasi media sangat diperlukan sebagai selfcontrol (Pambudi \& Novianti, 2018:187).

Pemahaman media literacy atau melek media secara sederhana adalah bagaimana khalayak mampu memilih atau menyaring isi pesan yang disampaikan oleh media. Khalayak mampu membedakan mana yang dianggap penting atau baik dan mana yang dianggap buruk. Pada dataran ini khalayak sudah semakin cerdas, aktif dan kritis. Bahkan khalayak tidak begitu saja mempercayai pesan yang disampaikan oleh media. Untuk itulah dibutuhkan adanya media edukasi dalam konteks media literacy. Wirodono (2006) mengemukakan tiga kategori khalayak yang rentan terhadap pengaruh buruk media, yakni anak-anak, remaja, dan kaum ibu (Novianti \& Fatonah, 2018:3).

Studi penelitian mengenai literasi media pada generasi milenial telah dilakukan sebelumnya oleh Silvana dan Darmawan (2018) yang meneliti mengenai "Pendidikan Literasi Digital di Kalangan Usia Muda di Kota Bandung". Penelitian tersebut menilik pada subjek khalayak kalangan usia muda berjumlah 5 orang dengan rentang usia 17-21 tahun yang merupakan pengguna aktif media sosial. Temuan yang diperoleh pada penelitian ini menunjukan pentingnya program literasi digital yang 
memberikan dampak positif bagi pengetahuan, pemahaman dan keterampilan dalam menggunakan media terutama media sosial yang saat ini sering dijadikan sumber informasi oleh khalayak terutama oleh kalangan yang berusia muda. Program ini memberikan kontribusi yang signifikan pada penyebaran informasi dalam menggunakan media massa terutama media sosial yang digunakan oleh kalangan usia muda sehingga ada kesadaran dalam menggunakan media. Pada pendidikan pelatihan (diklat) ini peserta belum semua mempunyai keahlian ini dikarenakan keahlian ini memerlukan latihan yang terus menerus dan konsisten sehingga mereka dapat melakukannya dengan baik. Pendidikan literasi digital merupakan solusi yang dapat dilakukan oleh pemerintah dan elemen masyarakat dan civitas akademika yang peduli terhadap kemajuan bangsa.

Sejarah literasi media dimulai tahun 1964 saat UNESCO mengembangkan model program pendidikan media yang akan dijalankan di seluruh dunia. Sejak saat itu berbagai Negara mulai menaruh perhatian terhadap literasi media, salah satunya adalah dengan melakukan literasi media atau pendidikan media melalui jalur pendidikan formal dan non-formal. Di Indonesia, kegiatan literasi media dikenal sejak tahun 2000-an setelah maraknya berbagai fenomena dampak media massa. Media massa sejak saat itu merupakan suatu hal yang akrab di kalangan masyarakat umumnya dan para remaja khususnya (Lutviah, 2010).

Penelitian tersebut memfokuskan kepada bentuk literasi digital yang meliputi kemahiran dalam photo-visual literacy, reproduksi literasi, percabangan literacy, informasi literacy, dan sosio-emosional literacy (Silvana \& Darmawan, 2018:150). Pada penelitian ini berfokus kepada kecakapan literasi media yang memiliki 7 (tujuh) unsur antaranya analysis, evaluation, grouping, induction, deduction, synthesis, dan abstracting. Media baru merupakan media yang akrab dengan remaja saat ini. Melarang bukan lagi menjadi sebuah pilihan. Menumbuhkan kesadaran untuk bisa melakukan dialog kritis dapat membantu remaja untuk lebih memahami makna dari pengalaman bermedianya (Fitryarini, 2016:56). Salah satu definisi yang dipakai secara luas adalah definisi dari The National Leadership Conference on Media Literacy yang merumuskan literasi media sebagai "kemampuan untuk mengakses, menganalisis, mengevaluasi, dan memproduksi media untuk tujuan tertentu". Definisi tersebut diperkuat oleh Sonia Livingstone dalam tulisan berjudul What is Media Literacy? Mendefinisikan literasi media sebagai "kemampuan untuk mengakses, menganalisis, mengevaluasi dan membuat pesan dalam berbagai konteks" (Livingstone: 2004).

Penelitian terdahulu tentang "Model Literasi Media Berbasis Kearifan Lokal Pada Masyarakat Kampung Dongkelan Kauman Daerah Istimewa Yogyakarta". Penelitian tersebut menghasilkan tiga temuan yaitu: 1) Kesadaran masyarakat melalui kearifan lokal dalam literasi media belum mampu memaksimalkan potensinya sendiri disebabkan masyarakat masih menjadi pengguna media yang pasif, tetapi terdapat Kelompok Penggiat Sekolah Masyarakat Desa yang menjadi pusat kegiatan masyarakat termasuk literasi media; 2) Model literasi media yang digunakan masyarakat Kampung Dongkelan Kauman adalah Protectionist. Model berbasis kearifan lokal meliputi 4 elemen yaitu kemampuan mengakses, menganalisis, mengevaluasi, dan memproduksi pesan; dan 3) memaksimalkan peran Sekolah Masyarakat Desa untuk meningkatkan kemampuan literasi media masyarakat (Setyaningsih, 2017:118). Perbedaan penelitian tersebut dengan penelitian ini terletak pada model literasi yang masih berpegang pada kearifan lokal daerah, sehingga lebih meliterasi pada kajian budaya lokal untuk menyaring berbagai dampak negatif dari media massa. Pada penelitian ini memfokuskan pada kecakapan literasi media yang dimiliki oleh mahasiswa yang memang dibekali dengan pengetahuan dan konsep teoritis mengenai literasi media. 
Beberapa konten media baik televisi maupun dalam media sosial, yang sering muncul antara lain yaitu perilaku kekerasan, informasi yang menyesatkan, kasus korupsi, pornografi, dan lain sebagainya yang jelas-jelas tidak bernilai pendidikan dan kemanusiaan selalu diberitakan media massa dan menjadi santapan mental masyarakat setiap saat. Tayangan media massa yang menarik bagi masyarakat pun kurang bahkan tidak mencerminkan budaya mereka. Padahal, idealnya, mental dan pikiran masyarakat dalam keseharian mesti disuguhi "makanan bergizi" dalam hal ini adalah informasi. Pada konteks ini adalah isi media massa yang bernilai pendidikan dan kemanusiaan yang diangkat dari budaya sendiri yang penuh nilai-nilai kearifan. Untuk memahami isi pesan media massa maka diperlukan sebuah kecakapan yaitu literasi media. Dengan kata lain, literasi media merupakan payung untuk melindungi masyarakat dari "guyuran" informasi media massa. Literasi media dapat dijadikan sebagai kunci bagi terbentuknya masyarakat yang cerdas dan kritis sehingga tidak mudah tergerus arus informasi dari media massa.

Literasi media baik yang konvensional maupun media baru mengajak audiens sebagai audiens maupun sebagai komunikator untuk memiliki kemampuan membaca ketika dihadapkan dengan media. Teknologi media, khususnya media baru mampu mengubah cara orang belajar, bermain dan bermasyarakat di dunia nyata. Berhubungan dengan sesuatu yang baru diperlukan keahlian yang baru pula apalagi subyek yang berhadapan adalah remaja. Berdasarkan penjabaran data di atas, maka tujuan penelitian ini untuk mengkaji dan menganalisis mengenai kecakapan literasi media dari para pelajar atau mahasiswa Broadcasting Universitas Mercu Buana, angkatan 2016.

\section{Metode Penelitian}

Metode analisis yang digunakan adalah metode kualitatif. Penelitian kualitatif dilaksanakan untuk membangun pengetahuan melalui pemahaman dan penemuan. Pendekatan penelitian kualitatif adalah suatu proses penelitian dan pemahaman yang berdasarkan pada metode yang menyelidiki suatu fenomena sosial dan masalah manusia. Pada penelitian ini peneliti membuat gambaran kompleks, meneliti kata-kata, laporan terinci dari pandangan responden dan melakukan studi pada situasi yang alami (Iskandar, 2009:11).

Objek penelitian ini adalah 7 (tujuh) mahasiswa Broadcasting angkatan 2016, alasan pemilihan subjek penelitian dengan pandangan bahwa mahasiswa broadcasting angkatan 2016 telah memiliki pemahaman mengenai literasi media. 7 orang informan yang dipilih dengan karakteristik; Telah mengikuti matakuliah komunikasi massa; diterpa dengan media massa konvensional maupun media baru minimal 2 jam per hari; minat pada kajian media; memiliki IPK minimal 3.00.

Tabel 1. Profile Subjek Penelitian

\begin{tabular}{clcccc}
\hline No. & \multicolumn{1}{c}{ Nama } & Nim & Usia & Jenis Kelamin & Semester \\
\hline 1. & Garibaldi & 44116010025 & 21 th & Laki-laki & Sem. 6 \\
2. & Dio Alfriansyah & 44116010034 & 21 th & Laki-laki & Sem. 6 \\
3. & Luthfi Maulana & 44116010100 & 21 th & Laki-laki & Sem. 6 \\
4. & Cahya Putri Abdi Rabbi & 44116010055 & 21 th & Perempuan & Sem. 6 \\
5. & Pika Nursahla & 44116010037 & 21 th & Perempuan & Sem. 6 \\
6. & Virda Syara & 44116010068 & 21 th & Perempuan & Sem. 6 \\
7. & Mutia Putri Kinanti & 44116010018 & 21 th & Perempuan & Sem. 6 \\
\hline
\end{tabular}

Sumber: Hasil olah data peneliti (2017) 
Gambaran identitas mahasiswa yang menjadi objek penelitian dapat dijabarkan dalam tabel 1 .

Teknik pengumpulan data pada data primer digunakan wawancara mendalam dengan 7 orang Informan yang dipilih dan sesuai dengan kriteria dalam objek penelitian. Data sekunder diperoleh melalui studi pustaka dari buku, karya tulis ilmiah dan bentuk data-data Pustaka yang memungkinkan diperoleh informasi tambahan.

Teknik analisis data menggunakan langkah sesuai Teori Miles, Huberman, dan Saldana(2014) yaitu menganalisis data dengan tiga langkah: kondensasi data (data condensation), menyajikan data (data display), dan menarik simpulan atau verifikasi (conclusion drawing and verification). Kondensasi data merujuk kepada proses menyeleksi, memfokuskan, menyederhanakan, mengabstraksi dan mentransformasi data yang terdapat pada catatan lapangan maupun transkrip (Miles \& Huberman, 2014:10). Proses selanjutnya penyajian data (data display), yaitu sekumpulan informasi tersusun yang memberi kemungkinan adanya penarikan kesimpulan dalam pengambilan tindakan. Proses penyajian data ini mengungkapkan secara keseluruhan dari sekelompok data yang diperoleh agar mudah dibaca dan dipahami, yang paling sering digunakan untuk penyajian data dalam penelitian kualitatif adalah dengan teks yang bersifat naratif. Proses terakhir kesimpulan dan verifikasi, data yang sudah diatur sedemikian rupa (dipolakan, difokuskan, disusun secara sistematis) kemudian disimpulkan sehingga makna data dapat ditemukan (Miles dan Huberman, 2014).

Teknik analisis data menggunakan analisis literasi media Potter (2004), yaitu: a) Analysis, berkaitan dengan kemampuan memahami isi dan konten serta membongkar dan mengkaji suatu pesan atau informasi dari sebuah media; b) Evaluation, dalam tahapan evaluasi ini kita diharapkan untuk mampu memberikan penilaian atas suatu pesan informasi yang media sampaikan; c) Grouping, tahapan ini kita diharapkan untuk mampu mengelompokan berbagai informasi yang kita peroleh dari suatu media dalam sebuah persamaan dan perbedaan tertentu; d) Induction, kemampuan menganalisis dan mengkaji suatu informasi dari yang bersifat khusus dalam lingkup kecil menuju pada yang bersifat umum secara menyeluruh; e) Deduction, kebalikan dari pada induksi yaitu kemampuan menganalisis dan mengkaji informasi yang bersifat umum kemudian menjabarkanya menjadi informasi yang bersifat khusus; f) Synthesis, kemampuan untuk merangkai kembali sebuah pesan atau informasi dari suatu media menjadi sebuah pesan dalam struktur baru yang berbeda dari sebelumnya; dan g) Abstracting, diharapkan kita sudah memiliki kemampuan dan kecakapan yang lengkap. Mulai dari menganalisis, mendeskripsikan, mencari titik poin permasalahan atau isu sampai kepada meringkas pesan dan menyajikanya kembali dengan bahasa yang lebih mudah dimengerti. Bila diringkas, maka tahapan kecakapan literasi media tersebut terbagai menjadi "kemampuan untuk mengakses, menganalisis, mengevaluasi dan membuat pesan dalam berbagai konteks" (Livingstone: 2004).

\section{Hasil Penelitian dan Pembahasan \\ Kemudahan Informan dalam Mengakses Media}

Kemudahan mengakses media massa konvensional dan media baru itu menunjukan pemakaian media massa yang tidak terbatas ruang dan waktu. Media konvensional yang banyak dikonsumsi oleh ketujuh Informan adalah televisi, walaupun ketujuhnya mengakui sudah tidak intens juga dalam menonton televisi. Para informan mengakui bahwa lebih sering menonton televisi sendirian tanpa didampingi orang tua. Para informan lebih suka menonton tayangan televisi sendirian daripada dengan adik-adik ataupun saudara lainnya. Secara umum ketujuh Informan menyukai tayangan yang bergendre informasi dan hiburan. “....kalo media konvensional televisi, tapi hanya untuk isi waktu kosong aja, sudah ngga sering-sering juga nonton tv mah....Seneng nonton tv sendiri, karena kalo sama mama, yangadanemenin dianonton sinetron....DiTV biasanya nonton acara talkshow, kaya Hitam Putih...." (Garibaldi, 15 November 2019). 
Pengalaman para informan dalam mengakses media massa diwakili pada kutipan wawancara di atas. Televisi masih menjadi pilihan utama dalam mengkonsumsi media massa. Hal ini menunjukan kemudahan cara akses dalam media konvensional yakni televisi, di mana dirumah ketujuh informan sudah tersedia media televisi. Bahkan ada informan yang memiliki akses media televisi sendiri dikamar tidurnya. "....nonton tv, dikamar tidur ada tv jadi ya kalau sedang tidak ada kerjaan pasti nonton tv....nonton sendiri, dikamar masing-masing sudah ada tv jadi ngga ada yang gerecokin. Seringnya nonton film sih, dirumah pakai tv kabel, udah ngga level nonton tv nasional....." (Dio Alfriansyah, 15 November 2019). Jaringan televisi menghadirkan bentuk analog dan digital, pada ranah analog dihadirkan stasiun televisi nasional yang dapat dinikmati secara gratis oleh masyarakat. Sedangkan bentuk televisi digital dapat dinikmati secara berlangganan, biasanya melalui layanan televisi kabel berbayar. Namun memberikan banyak pilihan tayangan yang beda kualitasnya dengan tayangan televisi nasional. Keberadaan televisi kabel menjadi alternatif pilihan media bagi informan, dengan alasan tidak menyukai tayangan di televisi nasional. “....televisi, tapi seringnya nonton streaming, jarang nonton tv elektronik....nonton sendiri, kadang sama teman, jarang nonton sama keluarga atau sodara dirumah.....Acara yang sering ditonton seperti film sama talkshow edukatif kaya Mata Najwa..." (Luthfi Maulana, 15 November 2019). Kebiasaan para informan yang lebih senang menonton televisi seorang diri saja, menunjukan daya pikir sebagai khalayak aktif yang tidak ingin menikmati media massa melalui pilihan orang lain, termasuk orang tua mereka sendiri. Para informan lebih suka berkuasa untuk memilih sendiri konten media yang dibutuhkan dan disukai. Sebagai generasi milenial, para narasumber memilih konten tayangan film dan talkshow untuk dinikmati dalam mengkonsumsi media televisi, baik itu televisi konvensional maupun televisi kabel. “.....mediakonvensional masih sering televisi, nontonnya tv kabel dirumah, lebih sering nonton sendiri, enak sih kalo nonton bareng keluarga, tapi pada punya kesibukan masingmasing....Banyak tontonan di TV kabel, bisa nonton film, musik, maupun berita....." (Mutia Putri Kinanti, 15 November 2019). Selain konten tayangan film dan talkshow, ada informan yang tertarik pada tayangan musik dan berita atau informasi. Dalam ranah media baru, ketujuh Informan sering mengakses media sosial, seperti Facebook, Instagram, Line, WhatsApp, dan Twitter. Melalui media sosial tersebut, ketujuh Informan sering melakukan beberapa aktivitas ini, antara lain: (1) Update status, (2) Browsing, (3) Share foto atau informasi, (4) Direct Message, (5) Follow, dan (6) Comment and Like. "....kalo media baru, saya sering pakai media sosial, fb, instagram, line, WA, untuk sarana komunikasi, cari informasi yang viral, update status....wifi di kampus, lumayan lah, bisa buat browsing cari tugas kuliah...." (Garibaldi, 15 November 2019).

Kutipan wawancara di atas menunjukan terpaan media baru yang melengkapi konsumsi media bagi para informan. Para informan sebagai generasi milenial memiliki alternatif pilihan media yang beragam. Hal itu tentunya membuat mereka rentan terhadap polusi informasi, sehingga kecakapan literasi media menjadi penting untuk dikuasai para informan. “.....instagram yang paling sering aku gunain, bisa untuk share berbagai hal, tau hal-hal yang viral....wifi kampus aku jarang pake juga sih, katanya sih mood-mood tan, kadang bisa cepet, kadang lemot. Dan ngga bisa download apa-apa kecuali ebook, pdf, yang dokumen-dokumen gitu deh...." Mutia Putri Kinanti, 15 November 2019).

Ketersediaan sarana wifi di Universitas Mercu Buana, cukup membantu dalam membuat tugas-tugas kuliah, walaupun dalam penggunaannya ada narasumber yang jarang mengakses internet menggunakan wifi kampus, dikarenakan keterbatasan dalam mengunduh video dan hanya bisa mengunduh dokumen, ebook, ataupun pdf saja. 


\section{Kemampuan Informan dalam Menganalisis Media}

Pada kemampuan menganalisis isi pesan media, ketujuh Informan mengakui bahwa mereka sudah menyadari efek negatif tayangan media massa maupun konten new media. Bahkan mereka mengetahui bahwa realitas di media massa dikonstruksikan sedemikian rupa berdasarkan ekonomi politik media massa tersebut.

"....TV mah isinya agenda setting semua, berita isinya sama semua, acara hiburan juga banyak settingannya, pakai penonton bayaran agar kesannya programnya menarik, padahal tidak mendidik. Di media baru semakin tidak ada filter, karena semua orang bisa menjadi komunikator untuk buat konten apa saja..." (Dio Alfriansyah, 15 November 2019).

Dampak media massa, baik televisi maupun media baru menurut informan mengacu kearah dampak negatif. Banyak acara yang dinilai tidak mendidik namun tetap eksis karena memiliki rating tinggi. Keberadaan media baru juga turut memberikan dampak negatif melalui penyebaran berita bohong dan informasi menyesatkan. “....baik TV maupun media baru semuanya punya dampak negative, makin kesini makin banyak seperti banyaknya hoax, program TV yang tidak mendidik dan banyak settingannya. Saya alami sendiri di tempat magang harus membuat program acara tv yang sebenarnya rekayasa, tapi saat nonton dengan keluarga dirumah, ternyata mereka percaya kalau acara itu beneran terjadi...." (Luthfi Maulana, 15 November 2019)

Pengetahuan para Informan terhadap regulasi dalam bidang penyiaran media konvensional dan media baru, diperoleh hasil bahwa Pemahaman ketujuh Informan mengenai regulasi media cenderung kurang. Kondisi ini diperkuat dengan kurangnya pemahaman terhadap regulasi isi media termasuk kurang pahamnya terhadap regulasi dari ranah media baru. Hal ini disampaikan oleh Cahya: “....UU ITE yang mengatur regulasinya police cyber mungkin.... isi UU ITE, musti nyontek dulu ngga hapal....." (Cahya Putri Abdi Rabbi, 15 November 2019).

\section{Kemampuan Informan dalam Mengevaluasi Media}

Hasil wawancara dengan ketujuh Informan semester 6 (enam) bidang studi Broadcasting, Universitas Mercu Buana, cukup memiliki kemampuan mengevaluasi tayangan atau konten media massa dengan baik. Dibuktikan dengan aktivitas mengkroscek informasi yang mereka terima dari media massa. "....harus melakukan konfirmasi atas informasi yang diperoleh, lebih-lebih pada media baru, informasi yang ada belum tentu benar, jadi dikroscek lagi...." (Virda Syara, 15 November 2019). Pendapat lain dari informan, menyebutkan pentingnya sebagai mahasiswa broadcasting untuk tidak langsung percaya dengan informasi dari satu sumber saja, melainkan harus memperoleh informasi dari berbagai sumber agar memperolehinformasiyang seimbang. Penerapan karakter media massa yang harus netral menjadi fokus penting dalam penerapan literasi media. “....iya tidak menelan mentah-mentah dari satu sumber saja, harus telusuri dari berbagai sumber, apalagi kita mahasiswa broadcasting sudah terlatih saat magang untuk mencari informasi dari berbagai sumber, sehingga informasi yang didapat seimbang, ini juga bagian dari karakter media massa yang harus netral...." (Luthfi Maulana, 15 November 2019)

\section{Kemampuan Informan dalam Memproduksi Pesan Media}

Hasil wawancara dengan ketujuh Informan menggambarkan bahwa mereka sudah mampu mencipta konten media. Bagi ketujuh Informan sendiri, menciptakan konten media sudah mereka aplikasikan dalam berbagai matakuliah. Baik itu karya dalam bentuk berita maupun karya non-berita. "....kuliah kami ada tugas-tugas produksi program tv, baik berita maupun non berita, jadi memang saya pernah terjun langsung buat konten berita sampai buat konten program drama...." (Pika Nursahla, 15 November 2019). 
Bentuk produksi pesan media yang dibuat oleh informan berupa karya audiovisual dalam format program acara baik itu berita televisi maupun non berita televisi. Produksi program berita seperti paket berita televisi, talkshow, dokumenter, dan feature. "....pernah dong buat produksi berita saat di matakuliah produksi berita tv, saya buat paket berita saat itu. Pernah buat program talkshow juga, dan film documenter saat di matakuliah feature documenter TV dan produksi non berita tv...." (Garibaldi, 15 November 2019). Produksi program non-berita yang pernah diaplikasikan oleh informan berupa film pendek. Di mana para informan dapat menyisipkan pesan-pesan lewat karya fiksi yang lebih menarik perhatian melalui karya film yang diproduksi. "....kita beruntung kuliah diranah broadcasting karena dibekali kemampuan memproduksi program tv baik berita maupun non berita saat itu saya buat film pendek....." (Dio Alfriansyah, 15 November 2019).

Berdasarkan hasil penelitian diperoleh data yang menggambarkan kecakapan literasi media dari para informan mahasiswa Broadcasting Universitas Mercu Buana, yakni (1) kecakapan literasi berkaitan dengan kemudahan dalam mengakses media; (2) kecakapan dalam menganalisis media; dan (3) kecakapan dalam mengevaluasi media. Hasil temuan penelitian dari wawancara dengan 7 (tujuh) mahasiswa sebagai informan memberikan gambaran bahwa posisi informan yang berkuliah di bidang Broadcasting turut membantu mereka dalam memperoleh kecakapan literasi media.

Saat inikemampuan literasimediamerupakan sebuah keahlian yang harus dimiliki setiap orang termasuk kaum remaja, karena mereka-lah yang menerima begitu kuatnya terpaan media massa. Bahkan terkadang terpaan dari media massa tersebut sulit untuk dikendalikan. Kemampuan literasi media bukan untuk menolak apalagi menggugat media agar tidak lagi beroperasi sebagai media massa. Kecakapan melakukan literasi media ini merupakan kemampuan dasar dalam memahami media dari aspek penggunaan hingga konten atau isi pesan yang ditampilkan oleh media massa. Melalui kemampuan tersebut diharapkan khalayak termasuk kaum remaja tidak mengalami berbagai dampak negatif dari keberadaan media massa, hingga muncul istilah "penyakit" disorientasi informasi

Konsep disorientasi informasi merupakan suatu keadaan yang membuat khalayak media kehilangan kesadaran dalam menikmati media. Begitu nikmatnya, sehingga khalayak tidak tahu harus berbuat apa dan bagaimana seharusnya. Bahkan khalayak tidak mengetahui lagi kebutuhan utamanya terhadap segala informasi yang disajikan media massa (Choirul: 2013). Hal tersebut mengakibatkan sehari-harinya mengkonsumsi informasi media yang tidak jelas, apakah informasi tersebut berguna atau sesuai dengan kebutuhan khalayak atau tidak.

Konsep literasi media ini tentunya penting dilakukan mengingat media konvensional seperti televisi dan new media memiliki dampak besar bagi masyarakat. Penyebabnya adalah pesan yang ditampilkan secara audio visual membawa terhadap khalayak, dampaknya meliputi segala aspek secara kognitif, afektif, dan konatif. Untuk itu konsep literasi media dapat memfilter dampak yang ditimbulkan media. Kemampuan literasi media ini diperlukan kaum remaja yang secara khusus disebut generasi milenial, kerena kehidupan mereka dikelilingi oleh media massa. Dari hasil wawancara dapat dianalisis berbagai tahapan literasi media yang dijelaskan sebagai berikut:

\section{Kecakapan dalam Mengakses Media Konvensional dan Media Baru}

Hasil wawancara dengan Informan Mahasiswa Broadcasting Universitas Mercu Buana ditemukan bahwa mereka tidak kesulitan dalam mengakses media konvensional maupun media baru. Para Informan memiliki kemampuan dalam menggunakan media massa dengan sangat baik. Bahkan mereka telah menjadi bagian dari khalayak media karena berbagai fasilitas media 
massa dari cetak, elektronik, layanan internet dengan wifi gratis tersedia dan terjangkau disekeliling para Informan. Keberadaan fasilitas wifi gratis dapat dengan mudah didapatkan, bahkan di dalam kawasan Universitas Mercu Buana.

Kemudahan mengakses media massa konvensional dan media baru itu menunjukan pemakaian media massa yang tidak terbatas ruang dan waktu. Media konvensional yang banyak dikonsumsi oleh ketujuh Informan adalah televisi, walaupun ketujuhnya mengakui sudah tidak intens juga dalam menonton televisi. Informan mengakui bahwa lebih sering menonton televisi sendirian tanpa didampingi orang tua. Mereka juga lebih suka menonton tayangan televisi sendirian daripada dengan adik-adik ataupun saudara lainnya.

Media konvensional televisi paling dominan dipilih untuk dikonsumsi oleh ketujuh Informan, hal ini dapat dipahami bahwa keberadaan televisi masih dipandang sebagai media yang relatif murah dan mudah diakses dalam memperoleh hiburan maupun informasi. Walaupun beberapa Informan telah menggunakan televisi kabel untuk lebih memperluas lingkup hiburan dan informasi yang diperoleh tidak hanya dari televisi nasional semata. Di balik kuatnya posisi televisi, harus diingat pula bahwa industri pertelevisian juga menghadirkan berbagai permasalahan. Terutama disebabkan oleh konten atau isi pesan yang hadir disetiap tayangan televisi, yang sering mengabaikan fungsi pendidikan atau kecerdasan kepada khalayaknya. Masih banyak program televisi yang mengandung unsur kekerasan, pornografi, mistis dan halhal yang tidak rasional (Guntarto: 2006).

Mengakses dalam konteks penggunaan media bisa dimaknai sebagai kemampuan audiens media dalam mencari, mendapatkan, dan mengumpulkan informasi. Akses media sekarang ini bukan lagi hambatan, apalagi untuk audiens yang berada di kota besar. Maka akses terhadap media dapat dilakukan tanpa terbatas ruang dan waktu. Kemudahan tersebut juga berarti akan banyak paham maupun pencampuran nilai dan norma budaya yang menghegemoni khalayak khususnya ketujuh Informan.

Dalam ranah media baru, ketujuh Informan sering mengakses media sosial, seperti facebook, instagram, line, whats up, twitter. Melalui media sosialtersebut,ketujuhInformanseringmelakukan beberapa aktivitas ini, antara lain: (1) Update status, (2) Share foto atau informasi, (3) Direct Message, (4) Follow, dan (5) Comment and Like.

Akses media online dengan segala kemudahannya membuat kuantitas penggunaannya mempengaruhi ketujuh Informan. Khususnya keberadaan fasilitas wifi bisa dengan mudah diperoleh di Universitas Mercu Buana. Informan dalam kasus ini termasuk dalam kategori remaja di mana remaja sebagai generasi milenial saat ini merupakan sebuah segmen pasar, sebagai subkulture dan yang memimpin jalan dalam penggunaan new media (Fitryarini, 2016:54).

Waktu yang digunakan oleh para Informan untuk mengakses media, rata-rata mereka mengakses media minimal 6 (enam) sampai 8 (delapan) jam perhari. Tempatmereka mengakses internet dan tayangan televisi adalah di rumah dan di kampus. Melihat begitu besar waktu minimal yang dihabiskan para Informan dalam menerima terpaan media massa, maka literasi media muncul melihat banyaknya kenyataan bahwa konten media massa lebih condong ke arah hiburan semata, lalu mengabaikan fungsi media massa lainnya. Khususnya fungsi mendidik (to educate), fungsi media massa yang satu ini seakan terlupakan, dengan tuntutan rating dan like yang harus dipenuhi oleh televisi maupun media sosial.

Tayangan yang banyak disukai oleh ketujuh Informan, merupakan tayangan yang mereka butuhkan dan dapat memberikan kepuasan. Secara umum ketujuh Informan menyukai tayangan yang bergendre informasi dan hiburan seperti Hitam Putih, Mata Najwa, National Geographic. Penjabaran para Informan ini 
sejalan dengan Teori Uses and Gratification, teori ini menyebutkan bahwa khalayak secara aktif mencari media tertentu dan konten media tertentu pula, untuk memperoleh kepuasan yang sesuai dengan kebutuhan khalayak tersebut.

Sudut pandang teori tersebut khalayak dikatakan aktif apabila telah mampu untuk mempelajari dan mengevaluasi berbagai jenis media serta konten media. Khalayak yang menonton suatu acara dari sebuah media massa disebabkan adanya kegunaan bagi mereka dan penghargaan dari upaya yang dilakukannya. Khalayak dengan senang hati akan memilih menonton berita, saat mereka memang membutuhkan informasi untuk mencapai tujuan tertentu.

Peradaban media yang sering disebut dalam era 4.0 saat ini membuat tidak seorang pun dapat meragukan kekuatan media massa. Media massa sudah menjadi sebuah ikon zaman, apapun yang terjadi dalam kehidupan umat manusia tidak sedetik pun terlewat oleh mata media massa. Hal itu menunjukan bahwa kecakapan dalam mengakses media massa merupakan sebuah keharusan. Individu yang belum mampu mengakses media massa, maka tertinggal berbagai informasi yang berkembang. Kaum remaja saat ini yang menjelma sebagai agen perubahan menyadari akan hal ini, lalu dengan sifatnya yang serba ingin tahu, mereka menggunakan media untuk selalu memperbaharui informasi yang mereka terima.

Gambaran lain dalam hal penggunaan media televisi dan media baru dikalangan remaja mahasiswa angkatan 2016 cukup memberikan angin segar. Para Informan setidaknya memiliki referensi lain dalam mencari informasi dan hiburan. Pada satu sisi kemampuan para Informan dalam mengakses media massa terbilang sangat tinggi, walaupun terdapat hal yang perlu diwaspadai yaitu kebutuhan untuk membaca media cetak atau artikel-artikel cetak, masih sangat minim. Para Informan lebih memilih membaca informasi melalui media online. Kelemahan dari media online yang harus diperhatikan adalah dapat memecah fokus audiens, hal ini dikarenakan banyak tampilan lainnya yang mendistorsi perhatian audiens. Bukan lagi membaca informasinya, tetapi lebih tertarik untuk meng"klik" iklan atau hal lain yang lebih menarik perhatian.

Berdasarkan hasil wawancara dengan ketujuh Informan berkaitan dengan kemampuan mengakses media massa, memperkuat pembahasan kasus ini bahwa masyarakat khususnya mahasiswa angkatan 2016 Bidang Studi Broadcasting Universitas Mercu Buana merupakan kaum remaja pengguna media massa yang aktif. New media khususnya media sosial dimanfaatkan oleh ketujuh Informan secara maksimal untuk keperluan sehari-hari seperti mencariinformasiuntuk tugas-tugas kuliah, untuk mendukung perekonomian mereka misalnya bisnis online dan sebagainya. Penggunaan media massa baik konvensional maupun media baru masih dalam ranah mencari informasi dan hiburan.

\section{Kemampuan Menganalisis Media Konvensional dan Media Baru}

Analisis merupakan kemampuan yang dapat membantu seseorang dalam menjelaskan bentuk pesan, struktur, segmen, dampak pesan, dan lain sebagainya. Analisis berkaitan dengan kemampuan untuk mencari, mengubah, dan memilih informasi disesuaikan dengan kebutuhan individu. Analisis merupakan aspek kompetensi personal lainnya selain kemampuan mengakses. Kemampuan ini lebih kepada melihat dari pemahaman kritis pengguna media. Sisi ini lebih melihat dan menekankan kemampuan pemahaman dan interpretasi mahasiswa dalam melihat, membaca dan mendengarkan produk media yang tersaji (Poter: 2004).

Pada kemampuan menganalisis isi pesan media, ketujuh Informan mengakui bahwa mereka sudah menyadari efek negatif tayangan media massa maupun konten new media. Bahkan mereka mengetahui bahwa realitas 
di media massa dikonstruksikan sedemikian rupa berdasarkan ekonomi politik media massa tersebut. Hal ini dapat dicermati lebih lanjut, karena para Informan ada di bidang Broadcasting, di tingkat semester 6 (enam), sehingga mereka sudah memperoleh materi perkuliahan yang mampu membuat mereka "melek" akan media.

Identifikasi literasi media khalayak media, terdapat ahli media Art Silverblatt yang mengelompokkan ada 7 (tujuh) karakteristik, salah satunya adalah adanya kesadaran akan dampak media pada individu dan masyarakat. Menurut Silverblatt, jika kita mengabaikan dampak media terhadap hidup kita, kita akan menanggung resiko terperangkap dan terbawa oleh arus perubahan daripada mengendalikan atau memimpinnya (Inda Fitryarini, 2016:61).

Karakteristik khalayak literasi media lainnya adalah kemampuan untuk menikmati, memahami dan menghargai isi media. Hal ini bukan berarti hidup seperti seorang pemarah, tidak berhubungan dengan media atau selalu curiga pada efek berbahaya dan degradasi budaya (Inda Fitryarini, 2016:62). Karakteristik tersebut, perlu ditanamkan bahwa literasi media bukan berarti anti media, namun lebih kepada kemampuan untuk meningkatkan kemampuan khalayak khususnya para Informan yang merupakan generasi muda untuk lebih terbuka terhadap perkembangan teknologi komunikasi dan menjadikan pengetahuan sebagai filter dalam mencegah dampak negatif media massa.

Ketujuh Informan juga sudah sangat mengetahui adanya agenda setting media, dengan adanya "penonton bayaran" dalam berbagai acara di televisi. Pengetahuan ketujuh Informan ini diakui mereka dapatkan langsung dari realitas program televisi nasional Indonesia, dan lagi mereka memperoleh banyak cerita dari senior mereka yang magang ataupun sudah bekerja di industri media. Sehingga mereka tidak lagi menganggap bahwa sebuah tayangan adalah fakta tanpa rekayasa.
Terdapat konsep mengenai bangunan literasi media, yang terdiri dari dua bagian: Pertama, perhatian pribadi (personal locus), yaitu apa yang kita konsentrasikan. Jika pondasi pada lokus pribadi sudah baik maka kita mampu membangun tiang-tiang bangunan literasi media yang disebut dengan struktur pengetahuan. Struktur pengetahuan literasi media dapat dibangun melalui proses filterisasi. Maka untuk membangun struktur pengetahuan diperlukan pemahaman mengenai segmentasi media, kepemilikan media dan dunia nyata. Melihat gambar kartun tentang agenda media dalam tayangan reality show maupun acara musik secara langsung merupakan struktur pengetahuan yang diperoleh dari dunia nyata (Faizal, 2012:67).

Sisi lain pemahaman kritis untuk menganalisis media selain diperlukan pemahaman terkait kepemilikan media, tidak kalah pentingnya adalah pemahaman remaja tentang regulasi media. Pada level regulasi, perjuangan dilakukan dengan melakukan upayaupaya untuk melahirkan perundangundangan yang menjamin hak-hak publik ketika berhadapan dengan media (Faizal, 2012:67).

Di Indonesia, Komisi Penyiaran Indonesia (KPI) merupakan salah satu wujud perjuangan untuk mengembalikan frekuensi penyiaran pada ranah publik, yang mesti dimanfaatkan sebesarbesarnya untuk kepentingan publik. Pada level produksi, advokasi dilakukan dengan sasaran para pekerja media. Pada level masyarakat, digarap upaya untuk membekali khalayak dengan kemampuan dan kesadaran media literasi. Pemahaman regulasi media yang baik sebenarnya akan mengantarkan seseorang untuk lebih peka dan kritis terhadap setiap tindakan yang dilakukan media, apakah bertentangan, menyimpang atau bahkan menjadikan khalayak semakin tidak tercerahkan. Untuk itu kompetensi personal dari aspek pemahaman tentang regulasi ini menjadi dasar ukuran tingkat kekritisan seseorang (Faizal, 2012:67). 
Pemahaman ketujuh Informan mengenai regulasi media cenderung kurang. Kondisi ini diperkuat dengan kurangnya pemahaman terhadap regulasi isi media termasuk kurang pahamnya terhadap regulasi dari ranah media baru. Kondisi ini disebabkan beberapa faktor yaitu para Informan kurang aktif dalam hal mencari informasi terkait regulasi pemerintah terhadap media. Padahal pemahaman akan regulasi media yang baik akan bermanfaat bagi para Informan dalam meningkatkan pemahaman kritis mereka serta rambu-rambu ketika suatu saat mereka akan memproduksi pesan. Ketujuh Informan sendiri mengetahui bahwa KPI sebagai badan regulasi untuk penyiaran, namun mengaku lupa akan isi dari regulasi yang berlaku untuk ranah penyiaran tersebut.

\section{Kemampuan Mengevaluasi Media Konvensional dan Media Baru}

Evaluasi merupakan kemampuan menghubungkan antara pesan media yang diterima dengan pengalaman. Mengevaluasi informasi berdasarkan parameter seperti kebenaran, kejujuran, dan kepentingan dari produsen pesan. Melalui proses evaluasi dapat menyadarkan bahwa khalayak tetap memiliki hak prerogratif dalam memaknai pesan media untuk dirinya sendiri (Potter: 2004).

Ketujuh Informan ternyata cukup mampu melakukan evaluasi berdasarkan parameter tersebut. Hal ini dilakukan para Informan dengan akses media massa sebagai media hiburan dan informasi, khususnya sebuah informasi yang dicek kembali dengan sumber lainnya. Tidak begitu saja percaya dengan satu sumber media saja. Bahkan tidak menutup kemungkinan informan akan mendiskusikan dengan teman atau mereka bawa ke ruang kelas sebagai bahan pertanyaan saat kuliah.

Berdasarkan perilaku ketujuh Informan tersebut ditahap evaluasi maka mereka termasuk ke dalam kategori khalayak aktif.
Seperti sudah diketahui bahwa khalayak terbagi menjadi khalayak pasif dan khalayak aktif. Jumlah dari khalayak pasif jauh lebih besar dibandingkan khalayak aktif. Khalayak pasif itu seperti diam saja, menerima mentahmentah ketika menerima informasi dari media massa dan yang memperburuknya lagi membuat khalayak pasif tidak berdaya menerima semua gempuran informasi yang simpangsiur dari media massa (Faizal, 2012:67).

Hasil wawancara dengan ketujuh Informan semester 6 (enam) bidang studi Broadcasting, Universitas Mercu Buana, cukup memiliki kemampuan mengevaluasi tayangan atau konten media massa dengan baik. Dibuktikan dengan aktivitas mengkroscek informasi yang mereka terima dari media massa.

\section{Kemampuan Memproduksi Pesan Media Konvensional dan Media Baru}

Content Creation atau memproduksi pesan adalah bagian dari kreativitas pesanya itu kemampuan menyusun pesan atau ide dengan kata-kata, suara, atau gambar secara efektif sesuai dengan kaidah-kaidah ilmu komunikasi. Menciptakan media berkaitan dengan produksi dan distribusi isi media, juga berkaitan dengan kompetensi komunikasi (Potter: 2004).

Hasil wawancara dengan ketujuh Informan menggambarkan bahwa mereka sudah mampu mencipta konten media. Berpegang pada konsep batasan literasi media Livingstone yang meliputi akses, analisis, evaluasi dan mencipta konten; menempatkan ketujuh Informan sebagai khalayak aktif yang tentunya dengan latar belakang keilmuan dibidang broadcasting tentunya kemampuan mencipta konten media sudah menjadi tugas kuliah mereka disepanjang perjalanan kuliah. Bahkan di Universitas Mercu Buana, Program Studi Ilmu Komunikasi, menyediakan format tugas akhir yang berbasis pembuatan karya atau aplikatif. Untuk bidang 
studi broadcasting sendiri sudah meluluskan banyak mahasiswa dengan tugas akhir aplikatif tersebut, dengan ciptaan konten media seperti film dokumenter, maupun film pendek.

Bagi ketujuh informan sendiri, menciptakan konten media sudah mereka aplikasikan dalam berbagai matakuliah. Baik itu karya dalam bentuk berita maupun karya non-berita. Dari hasil wawancara menunjukkan bahwa para Informan semester 6 (enam) bidang studi broadcasting, Universitas Mercu Buana sudah memiliki kemampuan memproduksi pesan media. Didukung dengan bidang studi yang memang konsen dengan ranah broadcasting atau penyiaran yang sangat dekat dengan media massa. Melalui matakuliah yang terdiri dari teori dipadu langsung dengan praktikum membuat para informan mampu untuk mengaplikasikan literasi media melalui karya produksi ciptakan mereka sendiri. Panduan dari ranah teoritis memberikan panduan bagi para informan dalam memproduksi konten media.

\section{Simpulan}

Disimpulkan bahwa kecakapan literasi media dari ketujuh Informan, meliputi kemampuan dalam mengakses, menganalisis, mengevaluasi, dan memproduksi pesan media massa baik konvensional maupun media baru. Secara kemampuan kecakapan literasi media ketujuh mahasiswa sebagai Informan dapat dikatakan telah memenuhi syarat-syarat kecakapan literasi media. Di mana posisi para informan terkait dekat dengan bidang penyiaran, dengan bekal teori serta praktek melalui matakuliah yang diperoleh mampu memberikan daya kritis pada pemikiran para informan dalam memilih dan mengkonsumsi konten media. Kontribusi penelitian ini untuk menyadarkan generasi muda, khususnya informan mahasiswa Broadcasting Universitas Mercu Buana akan pentingnya memiliki kecakapan literasi media. Dengan begitu generasi muda mampu menjadi agen literasi media bagi masyarakat disekitarnya.

\section{Daftar Pustaka}

APJII. (2017). Infografis Penetrasi \& Perilaku Pengguna Internet Indonesia 2017. <https:// web.kominfo.go.id/sites/default/files/ Laporan\%20Survei\%20APJII 2017 v1.3.pdf $>$ diakses pada 12/09/2020 Choirul, A. (2013). Tingkat Literasi Media Berbasis Kompetensi Individual Mahasiswa Fakultas Dahwah dan Ilmu Komunikasi IAIN Sunan Ampel Surabaya. Prosiding IAIN Sunan Ampel Surabaya. Retrieved from https:// core.ac.uk/download/pdf/34212289.pdf Faizal, A. R. (2012). Apa Makna Literasi Media Sesungguhnya? In Meretas Jalan Sosialisasi Literasi Media di Indonesia. Jakarta: KPIPusat Fitryarini, I. (2016). Literasi Media Pada MahasiswaProdiIlmuKomunikasiUniversitas Mulawarman. Jurnal Komunikasi, 8(1), 51-67. http://dx.doi.org/10.24912/jk.v8i1.46 Guntarto. (2006). An Assesment of Children's Television Programmer in Indonesia. YPMA Iskandar. (2009). Metodologi Penelitian Kualitatif. Jakarta: Gaung Persada.

Livingstone, S. (2004). What is Media Literaci?. Intermedia. Lutviah. (2010). Citizen Jurnalisme Berbasis Blog Group dan Penerapannya Untuk Literasi Media: Studi Kasus Kompasiana. com. Retrieved from www.pustaka.ut.ac. $\mathrm{id} / \mathrm{dev} 25 / \mathrm{pdfprosiding} 2 /$ fisip201018.pdf. Miles, M. B., Huberman, A. M., \& Saldana, J. (2014). Qualitative Data Analysis, A Methods Sourcebook, Edition 3. USA: Sage Publications. Terjemahan Tjetjep Rohindi Rohidi, UI-Press. Morissan, M. (2014). Media Sosial dan Partisipasi Sosial di Kalangan Generasi Muda. Jurnal Visi Komunikasi, 13(01), 5068. http://dx.doi.org/10.22441/jvk.v13i1.366 Novianti, D., \& Fatonah, S. (2018). Literasi Media Digital di Lingkungan Ibu-Ibu Rumah Tangga di Yogyakarta. Jurnal Ilmu Komunikasi, 16(1), 1-14. Diakses dari http://jurnal.upnyk.ac.id/index. $\mathrm{php/komunikasi/article/view/2678}$ 
Pambudi, S. T., \& Novianti, D. (2018). Model Literasi Media di Lingkungan Rumah Panti Asuhan. Jurnal Ilmu Komunikasi, 16(2), 187196. Diakses dari http://jurnal.upnyk.ac.id/ index.php/komunikasi/article/view/2694

Potter, James W. (2004). Theory of Media Literacy: a Cognitive Approach. California: Sage Publications. Qudratullah. (2016). Peran dan Fungsi Komunikasi Massa. UINAlauddin Makassar: Jurnal Dakwah Tabligh, 17(2), 41-46.

Setianto, W. A. (2018). Literasi Konten Radikal di MediaOnline.JurnalImuKomunikasi, 16(1), 75-88. Diakses dari http://jurnal.upnyk.ac.id/ index.php/komunikasi/article/view/2684

Setyaningsih, R. (2017). Model Literasi Media Berbasis Kearifan lokal pada Masyarakat Kampung Dongkelan
Kauman Daerah Istimewa Yogyakarta. Komuniti: Jurnal Komunikasi dan Teknologi Informasi, 9(2), 118-125. https:// doi.org/10.23917/komuniti.v9i2.4520 Silvana, H., \& Darmawan, C. (2018). Pendidikan Literasi Digital di Kalangan Usia Muda di Kota Bandung. Pedagogia: Jurnal Ilmu Pendidikan, 16(2), 154-167. https://doi.org/10.17509/pdgia.v16i2.11327 Terakota. (January 26th, 2020). Narasi "Menyesatkan" di Media Arus Utama. Retrieved from https://www.terakota.id/ narasi-menyesatkan-di-media-arus-utama/ Wirodono, S.(2006).Matikan TV-mu:TerorMedia Televisi di Indonesia. Yogyakarta: Resist Book. 